\title{
Pemutakhiran Kebijakan Smart Health City Secara Kolaboratif Sebagai Upaya Pelaksanaan Revolusi Mental: Studi Di Kota Depok
}

\section{${ }^{1}$ Adam Dwi Julianysah, ${ }^{2}$ Dyah Ayu Febriani, ${ }^{3}$ Hisyam Yusril Hidayat, ${ }^{4}$ Mohammad Hernanda Trianggoro, ${ }^{5}$ Vanissa Noorizqa Prastowo}

\author{
${ }^{1}$ Universitas Indonesia, Indonesia; adam.dwi@ui.ac.id \\ ${ }^{2}$ Universitas Indonesia, Indonesia; dyah.ayu76@ui.ac.id \\ ${ }^{3}$ Universitas Indonesia, Indonesia; hisyam.yusril@ui.ac.id \\ ${ }^{4}$ Universitas Indonesia, Indonesia; mohammad.hernanda@ui.ac.id \\ ${ }^{5}$ Universitas Indonesia, Indonesia; vanissa.noorizqa@ui.ac.id
}

\begin{abstract}
The problem in the health sector is one of the complicated problems faced by the government, this is evidenced by the extraordinary events (KLB) in various regions, one of which is the Hepatitis A outbreak in Depok that accumulates 306 cases. The main cause of these outbreaks is the low awareness and mentality of the public regarding the application of healthy and clean lifestyles and the government's preventive ability in terms of policies. Seeing this problem, the City Government of Depok has a strategic plan in the form of the Smart Healthy City (SHC) Depok policy as one of the policy efforts in order to improve the quality of public health through implementing technology and increasing competence in realizing the policy. This paper aims to review how the SHC Depok strategic plan policy can be collaboratively updated to carry out a mental revolution not only at the local government level, but also that policy can be understood by the public. The goal of the mental revolution is not only towards society, but also from the side of the government and various other parties. This paper was compiled from primary data in the form of in-depth interviews with various informants and secondary data from books, journals, and electronic sources. The expected outcome of the SHC Depok policy renewing itself is to improve the quality of services and improve the quality of public health based on preventive and collaborative actions.
\end{abstract}

Keywords: Collaborative Governance, Local Government, Public Policy, Mental Revolution, Smart Health City

\section{Pendahuluan}

Kesehatan merupakan salah satu kebutuhan dasar negara sebagai bentuk perwujudan pemenuhan hak bagi setiap masyarakat yang telah dilindungi oleh Undang-Undang Dasar. Di Indonesia sendiri, pelayanan jaminan kesehatan juga telah diatur dalam Undang-Undang No. 23 tahun 1992 yang kemudian diganti dengan Undang-Undang no. 36 Tahun 2009 tentang kesehatan. Undang - Undang tersebut menegaskan bahwa setiap orang mempunyai hak yang sama dalam memperoleh akses atas sumber daya di bidang kesehatan dan memperoleh pelayanan kesehatan yang aman, bermutu, dan terjangkau. Tingkat kesehatan masyarakat sangat berpengaruh terhadap tingkat kesejahteraan masyarakat, hal ini dikarenakan rendahnya tingkat kesehatan merupakan salah satu pemicu terjadinya kemiskinan (Widiastuti, 2017). Terjadinya kemiskinan akan menyebabkan seseorang tidak bisa mendapatkan pelayanan kesehatan secara maksimal serta tidak tercukupinya gizi yang baik. Melihat adanya hal tersebut, perlu diwujudkan suatu kebijakan yang diambil oleh pemerintah dalam memberikan jaminan layanan kesehatan yang baik kepada masyarakat sehingga mampu meningkatkan tingkat kesehatan di masyarakat (Widiastuti, 2017).

Berbicara mengenai tingkat kesehatan, Kota Depok, Jawa Barat belum lama ini mengalami kejadian luar biasa (KLB) dalam hal kesehatan yaitu penyebaran hepatitis A yang terjadi pada tahun 2019 (CNN Indonesia, 2019) Menurut Dirjen Pencegahan dan Pengendalian 
Penyakit Kementerian Kesehatan Republik Indonesia, dr. Anung Sugihantono menyebutkan bahwa sampai tanggal 3 Desember 2019 terdapat 262 kasus dimana dari hasil pemeriksaan 171 orang merupakan penderita baru dan 90 orang pernah mengalami hepatitis A. Kejadian ini diawali dari temuan kasus yang menjangkit puluhan siswa SMPN 20 Kota Depok yang kemudian menyebar secara menyeluruh kepada masyarakat di Kota Depok (Billy, 2019). Melihat banyaknya kasus Hepatitis A di Kota Depok yang terjadi pada tahun 2019, maka, kasus tersebut memang dikategorikan sebagai kejadian luar biasa (KLB) oleh Kementerian Kesehatan Republik Indonesia dikarenakan merupakan penyakit menular yang menjangkit masyarakat secara masif serta menuai kerugian bagi daerah itu sendiri (Alam, 2019).

Hal yang menjadi penyebab dari munculnya penyakit Hepatitis A adalah karena kondisi sanitasi yang buruk, makanan yang tidak higienis, dan kurangnya kesadaran masyarakat akan kesehatan diri sendiri (Laila, et al., 2018). Selain itu, penelusuran lainnya yang dilakukan oleh Kementerian Kesehatan Republik Indonesia menuturkan bahwa penyebab KLB Hepatitis A di Depok disebabkan oleh ketidakbersihan dalam menyediakan makanan terutama jajanan kantin serta perilaku masyarakat Kota Depok yang belum mementingkan kesehatan padahal penularan virus Hepatitis A dapat melalui makanan, minuman, maupun yang tersisa di piring makanan yang telah dicuci (Wiyanti, 2019).

Melihat adanya kasus KLB yang salah satunya dikarenakan masih rendahnya kesadaran masyarakat Kota Depok akan kesehatan, diperlukan adanya revolusi mental yang dilakukan Pemerintah Kota Depok berkolaborasi dengan seluruh elemen masyarakat sebagai penunjang peningkatan kesadaran masyarakat akan pola hidup sehat. Berdasarkan pengertiannya, menurut Ermaya (2015) dalam (Suwardana, 2017) menjelaskan bahwa revolusi mental merupakan perubahan pola pikir seseorang berdasarkan (nilai agama, tradisi, budaya, dan falsafah bangsa) sehingga membentuk karakter yang bermanfaat bagi lingkungan sekitarnya. Dengan kata lain, revolusi mental dapat terbangun atas tiga hal yaitu; cara berpikir (mindset), cara meyakini (transendental value), dan cara bersikap (behavioral approach). Berdasarkan peristiwa Hepatitis A yang menjadi KLB tersebut, jelas bahwa pola pikir dan sikap masyarakat Kota Depok perlu ditingkatkan tentang pentingnya kesehatan serta dukungan dan penyediaan pelayanan dari Pemerintah Kota (Pemkot) Depok itu sendiri.

Salah satu upaya Pemkot Depok dalam rangka meningkatkan kualitas kesehatan masyarakatnya serta adanya revolusi mental adalah dengan menghadirkan program unggulan berupa kebijakan Smart Healthy City (SHC) Depok yang menjadi program unggulan tambahan dan baru dimasukkan dalam Rencana Pembangunan Jangka Menengah Daerah (RPJMD) pada tahun 2017 untuk RPJMD 2016-2021 (Depok.go.id, 2017). SHC Depok memiliki beberapa aspek program berupa regulasi dankelembagaan kesehatan, cakupan jaminan kesehatan, kualitas, dan kuantitas layanan kesehatan 24 jam, program kota sehat, dan pengembangan sistem manajemen kesehatan daerah berbasis IT (Depok.go.id, 2017). Salah satu poin yang menarik peneliti adalah adanya penyusunan kebijakan yang mengedepankan adanya regulasi yang komprehensif serta optimalisasi peran lembaga/forum mitra hingga ke tingkat kelurahan di bidang kesehatan serta menjaring kader atau sukarelawan kesehatan dari masyarakat demi mendukung terciptanya SHC (SHC) Depok (Depok.go.id, 2017).

Salah satu bentuk upaya realisasi SHC Depok, Pemkot Depok mengadakan Forum Kota Sehat hingga Kelompok Kerja (Pokja) kelurahan sehat dimana kegiatan yang diadakan berupa sosialisasi ke masyarakat mengenai pengelolaan sanitasi, hidup bersih dan sehat, pentingnya vaksin bagi anak, kegiatan minum obat cacing secara rutin, dan kegiatan lainnya yang berkaitan dengan kesehatan dengan memanfaatkan para aparatur sipil negara (ASN) dari tingkat Kota hingga Kelurahan serta melakukan rekrutmen kepada masyarakat untuk menjadi kader atau relawan dalam mendukung terealisasinya berbagai program Pokja kelurahan sehat 
(kotasehat.depok.go.id, 2020). Selain itu, upaya lainnya dalam menyukseskan SHC Depok adalah dengan adanya Germas (Gerakan Masyarakat Hidup Sehat) yang dikampanyekan oleh dinas kesehatan kota Depok pada acara peringatan hari kesehatan nasional (HKN) ke55 (Hasanah, 2019). Germas merupakan salah satu upaya revolusi mental bagi masyarakat Kota Depok untuk menyadarkan betapa pentingnya kesehatan dengan melakukan aktivitas fisik secara teratur, konsumsi buah, dan sayuran, melakukan cek kesehatan secara rutin, serta menghindari asap rokok, dan menjaga kebersihan (Adi, 2019).

Salah satu kelurahan di Kota Depok, Kelurahan Tapos juga turut menyukseskan Germas. Tercatat sebanyak 700 orang masyarakat Tapos mengikuti acara Germas yang diadakan oleh Kelurahan Tapos, tidak hanya sekedar acara biasa, Puskesmas Tapos juga menyosialisasikan penerapan pola hidup sehat dengan CERDIK yang memiliki arti cek kesehatan secara rutin, penghilang asap rokok, rajin berolahraga, Istirahat yang cukup, dan Kelola stres (Marques, 2018).

Sejauh ini, tidak hanya Pemkot Depok yang peduli dengan kualitas kesehatan masyarakatnya terutama dalam rangka menuju SHC Depok, tetapi organisasi nonpemerintahan seperti komunitas sehat kenko no kai juga melakukan suatu bentuk kegiatan seminar dan talkshow gratis kepada masyarakat Depok sebagai salah satu upaya untuk menjaga kesehatan dengan mengubah pola pikir masyarakat melalui pola hidup yang sehat dan baik (Rubiakto, 2020). Kenko no kai bekerja sama dengan rekanan komunitas kesehatan di Jepang memiliki 4 program utama yaitu, mengedukasi dan memberikan pendidikan tentang menjaga kesehatan melalui pola hidup yang sehat, program deteksi dini penyakit serta program terapi kesehatan. Namun, hal yang menjadi perhatian khusus dalam program yang diadakan oleh komunitas Kenko no kai ini sendiri adalah bagaimana cara mengedukasi masyarakat untuk menjaga kesehatan dengan pola hidup yang sehat karena pada dasarnya masyarakat awam masih kurang paham bagaimana cara menerapkan pola hidup yang sehat (Rubiakto, 2020).

Berbagai upaya telah dilakukan oleh Pemkot Depok, masyarakat, hingga organisasi non-pemerintahan dalam rangka membangun serta merekonstruksi pemikiran masyarakat dalam rangka meningkatkan kualitas kesehatan masyarakat Kota Depok, tetapi nampaknya kebijakan yang ada perlu diadakannya pengkajian lebih lanjut melihat bahwa walaupun Kota Depok telah memiliki rencana strategis dinas kesehatan berupa menjadikan masyarakat yang mandiri untuk hidup sehat, nyatanya kesadaran masyarakat Kota Depok akan hidup sehat masih belum baik dan perlu dilakukan revolusi mental mengenai kesehatan baik bagi diri sendiri atau kepada lingkungan sekitar (Depok.go.id, 2017). Disamping itu, kuantitas lokasi pelayanan kesehatan di Depok belum memadai melihat bahwa dalam rencana strategis Kota Depok 20162021 bahwa setidaknya setiap kelurahan memiliki 1 puskesmas bagi warganya, tetapi hingga penghujung tahun 2019 hanya ada 35 kelurahan yang memiliki puskesmas dari total 63 kelurahan yang ada di Kota Depok (Wartakota.com, 2019). Padahal, keberadaan puskesmas menjadi salah satu faktor infrastruktur penunjang yang penting dalam meningkatkan kesehatan masyarakat serta memberikan edukasi secara lebih dekat dengan masyarakat terutama dalam mencapai SHC Depok.

Selain kekurangan jumlah puskesmas pada setiap kelurahan yang ada di Depok, tenaga medis di Depok juga masih dinyatakan kurang dan membutuhkan sekitar ratusan jumlah tenaga medis untuk bekerja di puskesmas Depok. Kepala Dinas Kesehatan Kota Depok Novarita menyatakan bahwa tenaga kesehatan yang masih kurang yaitu pada bidan, perawat laboratorium, tenaga gizi, tenaga kesehatan keliling (kesling) dan kesehatan masyarakat.

Berdasarkan hal tersebut, tenaga kesehatan masyarakat menjadi hal yang paling banyak kurang di Kota Depok. Adapun tugas dari kesehatan masyarakat adalah mengampanyekan pola hidup sehat kepada masyarakat. Melihat hal tersebut dapat dinyatakan dengan kurangnya 
tenaga medis kesehatan masyarakat di Kota Depok menyebabkan masyarakat Depok kurang mengetahui bagaimana cara pola hidup sehat (Putra, 2019). Temuan dari Darmanto et al (2008) menunjukkan bahwa persepsi masyarakat terhadap layanan puskesmas berada pada posisi yang dianggap baik dengan persentase $(41,2 \%)$ dan dari dimensi tangible masih berada dalam tingkatan cukup baik yang mengisyaratkan dari segi fasilitas masih belum dapat memadai secara kuantitas dan kualitas. Temuan tersebut masih belum banyak berubah merujuk pada kondisi saat ini.

Pemkot Depok sendiri menanggapi berbagai permasalahan tersebut dengan adanya pencapaian tujuan menuju Depok Kota Sehat atau SHC (SHC) yang mencoba melakukan difusi teknologi, mengoptimalkan sumber daya yang tersedia, dan mendukung adanya aspek pembangunan berkelanjutan dalam sektor kesehatan dari dua sisi yaitu di masyarakat dan aparatur itu sendiri (Dinkes Depok, 2018). Difusi teknologi dilakukan dengan tujuan memberikan kemudahan dalam mengakses layanan yang ada. SHC sendiri memiliki tiga komponen yaitu 1) smart healthy citizen (warga sehat yang cerdas dan mengakses kesehatan dengan mudah memiliki kesadaran pentingnya kesehatan), 2) smart health governance (adanya aplikasi daring yang membantu administrasi pemerintahan menjadi lebih sederhana dan mudah), dan 3) smart healthcare (ditujukan dalam digitalisasi fasilitas kesehatan). Namun, adanya fokus ini belum menjangkau dari sisi kapabilitas dari tenaga kesehatan dan pentingnya peran serta kesadaran masyarakat untuk dapat menerapkan pola hidup yang sehat. Penelitian dari Susanti et al (2018) mengungkapkan bilamana suatu kelompok masyarakat memiliki kesadaran penting terkait kesehatan akan mempengaruhi perilaku di masa depan dan memberikan pengaruh yang baik bagi masyarakat lainnya untuk saling menjaga kondisi kesehatan. Oleh karena itu perlu adanya dua fokus terkait peningkatan kapabilitas tenaga medis dan peningkatan kesadaran masyarakat terkait kesehatan.

Peran dari individu lain menjadi penting dalam meningkatkan kesadaran masyarakat. Sebagaimana yang dikatakan oleh Blum (1974) dalam Perangin-angin (2010) menyatakan bahwa derajat kesehatan dari individu atau masyarakat ditentukan oleh empat faktor utama yang sangat mempengaruhi. Faktor tersebut terdiri dari faktor perilaku, faktor lingkungan, faktor pelayanan kesehatan, dan faktor keturunan. Dari empat faktor tersebut, faktor lingkungan memengaruhi dengan persentase $40 \%$, selanjutnya faktor perilaku mempengaruhi $30 \%$, faktor pelayanan kesehatan memengaruhi sebesar $20 \%$, dan $10 \%$ dipengaruhi oleh faktor genetika. Melihat hal tersebut lingkungan dan perilaku menjadi unsur penting yang dapat membantu peningkatan kualitas masyarakat secara signifikan. Oleh karena itu perlu adanya pemutakhiran kebijakan kesehatan untuk mengakomodir dua hal tersebut. Sebelum memberikan rekomendasi untuk melakukan pemutakhiran diperlukan adanya telaah mendalam berkaitan dengan kondisi yang ada saat ini.

Selain itu, dibutuhkan adanya peran berbagai aktor yang dapat mewujudkan tujuan lebih efektif dibandingkan hanya mengandalkan peran dari pemerintah (Ihsanuddin \& Rahayu, 2019). Optimalisasi peran aktor-aktor dapat dilakukan dengan adanya penerapan collaborative governance yang diartikan sebagai pengaturan pengaturan satu atau lebih lembaga publik yang secara langsung melibatkan para pemangku kepentingan non-publik dalam proses pengambilan keputusan bersifat kolektif dan formal, berorientasi pada konsensus bersama, dan deliberatif serta yang bertujuan untuk membuat atau melaksanakan kebijakan publik atau mengelola program-program publik atau aset publik (Ansell \& Gash, 2007). Sebagaimana Model Collaborative Governance berikut ini: 


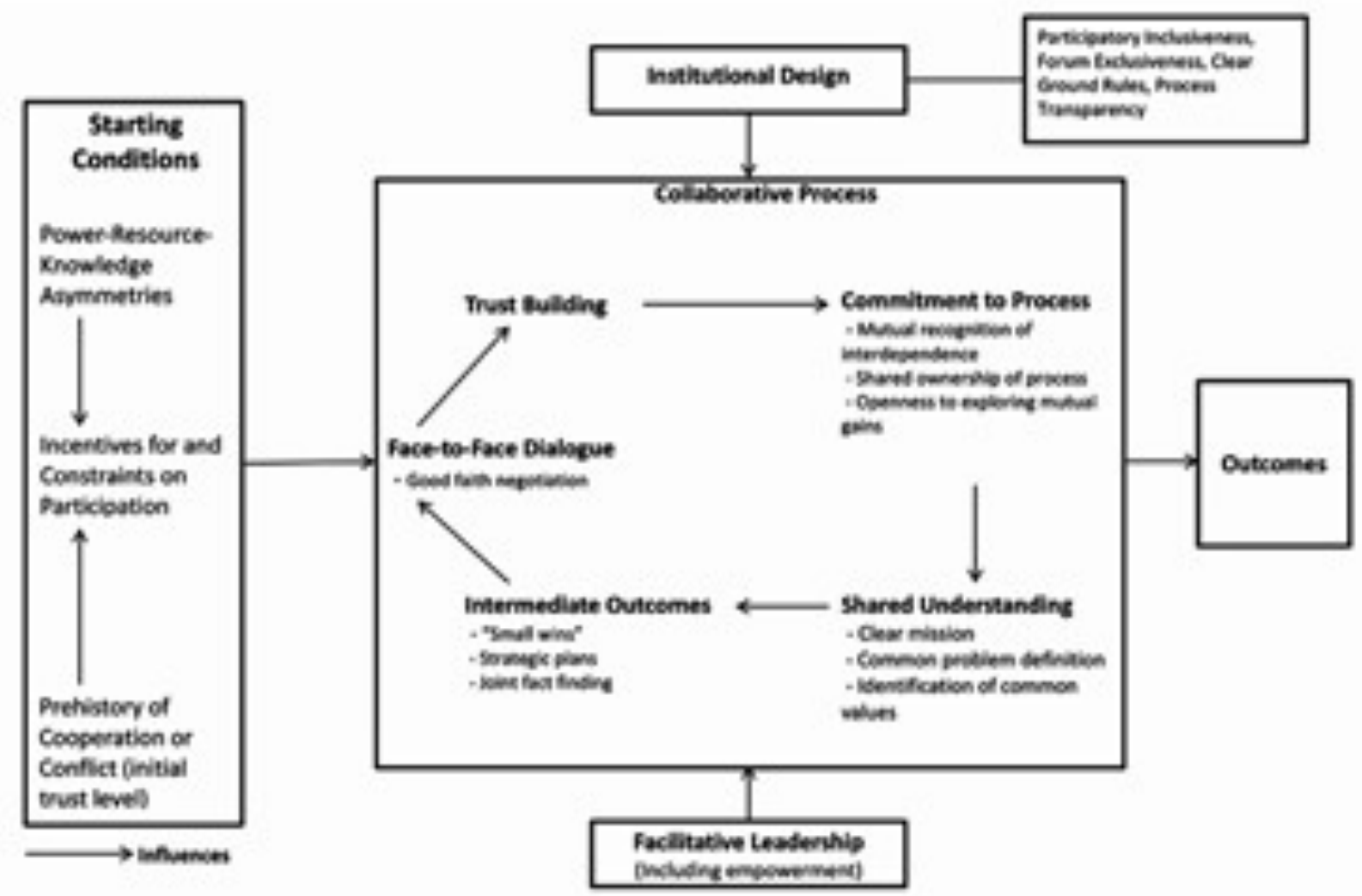

Sumber: Ansell and Gash, 2007

Gambar di atas merepresentasikan hubungan antara lembaga publik dengan aktor-aktor non-pemerintah dalam kolaborasi untuk memecahkan suatu permasalahan. Model tersebut memiliki empat variabel utama yaitu: 1) starting condition (kondisi awal) yang mencakup masing-masing sumber daya yang dimiliki oleh lembaga, tingkat kepercayaan, dan modal sosial selama kolaborasi berlangsung 2) institutional design (desain kelembagaan) yang didalamnya terdapat aturan dasar dalam menjalankan kolaborasi yang bersifat terbuka dan inklusif, 3) facilitative leadership (kepemimpinan fasilitatif) yang mencakup kemampuan pengelolaan manajemen serta pengambilan keputusan saat kolaborasi berlangsung, dan 4) collaborative process (proses kolaboratif) yang didalamnya mencakup penentuan masalah, penentuan tujuan, dan implementasi untuk mewujudkan kolaborasi yang efektif. Proses kolaboratif memegang peran penting pada proses kolaborasi antar berbagai pemangku kepentingan dan proses tersebut tidak bersifat linear dan akan terus bergulir menjadi sebuah siklus. Pada akhirnya, proses kolaboratif itu sendiri selalu berulang dan bersifat non-linear, sehingga dapat dilihat sebagai sebuah siklus (Ansell \& Gash, 2007).

Kerangka tersebut terbukti sudah dapat menyelesaikan berbagai permasalahan dari sektor kesehatan yang dibuktikan dengan temuan dari (Swastini, 2010; Nuraini, 2015; Muqirrobin, 2016; Hariyanto, 2016; Fitriana, 2017; Fauzi \& Rahayu, 2019). Dari temuan tersebut tergambar bahwa collaborative governance dapat menjadi main factor dalam meningkatkan kualitas kesehatan melalui pemutakhiran dari SHC. Oleh karena itu penelitian ini bertujuan untuk menganalisis Bagaimana Pelaksanaan Kebijakan Smart Health City Secara Kolaboratif di Kota Depok. 


\section{Metode Penelitian}

Penelitian ini menggunakan paradigma post-positivist yang didefinisikan oleh Morris et al (2009) sebagai metode campuran yang mencakup paradigma dalam pendekatan positivist dengan subjektivitas dari realitas dan bergerak dari cara pandang yang diadopsi dalam paradigma positivist. Sedangkan penggunaan metode kualitatif dimanfaatkan karena penelitian ini memerlukan pendapat dan penilaian dari para pemangku kepentingan yang berhubungan dengan kebijakan pelayanan kesehatan di Kecamatan Tapos, Kota Depok. Objek penelitian ini adalah mengenai upaya pemutakhiran dari strategi mewujudkan Kota Depok sebagai smart health city dari sudut pandang informan dalam penelitian ini dan adanya tinjauan literatur yang dilakukan untuk melengkapi data dari penelitian ini.

Dalam penelitian ini, teknik pengumpulan data yang peneliti gunakan adalah dilakukan dengan wawancara mendalam, studi kepustakaan, dan observasi yang tidak struktur di sekitar lokus penelitian yaitu di Kecamatan Tapos. Informan dalam penelitian ini adalah Herawati selaku Kepala Seksi Kemasyarakatan dan Pelayanan Kelurahan Tapos, Kecamatan Tapos, Kota Depok. Pertanyaan yang terdapat pada wawancara biasanya tidak terstruktur dan bersifat terbuka, sehingga bisa mendapatkan pandangan responden secara lebih mendalam (Creswell, 2009). Wawancara dalam penelitian ini digunakan untuk menguji kebenaran dan kemantapan data yang diperoleh yang berasal langsung dari narasumber. Narasumber yang diwawancarai dalam penelitian ini adalah orang-orang yang memiliki pemahaman terkait setiap kebijakan pemerintah melalui literasi.

Di dalam suatu proses penelitian, data yang telah dikumpulkan akan melalui tahap analisis data untuk menemukan hubungan antara data tersebut dengan teori. Neuman (2014) mendefinisikan analisis data sebagai proses sistematis untuk mengatur, mengintegrasikan, dan memeriksa dengan cara mencari pola dan hubungan di antara rincian spesifik. Lebih lanjut, Neuman menjelaskan bahwa data-data tersebut selanjutnya akan dihubungkan dengan konsep untuk memajukan generalisasi dalam rangka mengidentifikasi tema secara luas. Dalam penelitian ini, peneliti menggunakan teknik analisis data kualitatif. Setelah melewati proses pengumpulan data dengan menggunakan instrumen wawancara mendalam, peneliti melakukan pengolahan data berdasarkan data yang telah diperoleh dengan menggunakan analisis data kualitatif. Analisis data kualitatif merupakan serangkaian proses dan prosedur peralihan dari data berbentuk mentah di lapangan menjadi bentuk penjelasan, pemahaman maupun interpretasi dari subjek atau kondisi yang kita amati (Bryman, 2012).

\section{Hasil dan Pembahasan}

Kemampuan masyarakat terutama dalam rekonstruksi pola pikir bahwa kesehatan itu penting menjadi salah satu agenda penting revolusi mental masyarakat di Indonesia. Lebih spesifik lagi terutama terhadap berbagai kota di Indonesia yang ingin mengusung smart healthy city, salah satunya adalah Kota Depok. Dalam kehidupan sehari-hari, revolusi mental terkait dengan adanya membangun jiwa yang merdeka, mengubah cara pandang, pikiran, sikap, dan perilaku agar berorientasi pada kemajuan dan hal-hal yang modern, sehingga Indonesia menjadi bangsa yang besar dan mampu berkompetisi dengan bangsa-bangsa lain di dunia (kominfo.go.id, 2015).

Pada Kelurahan Tapos, Kota Depok sendiri, kesadaran masyarakat akan kesehatan menjadi perhatian khusus mengingat bahwa masih banyak masyarakat yang tidak mementingkan kesehatan, padahal, dalam wawancara mendalam yang telah dilakukan peneliti menunjukkan bahwa telah adanya berbagai penyuluhan dari dinas kesehatan Kota Depok melalui kader di Kelurahan Tapos, selain itu Kelurahan Tapos juga sering menyebarkan 
selembaran himbauan kepada warga mengenai pentingnya hidup sehat. Pernyataan tersebut terdapat dalam kutipan wawancara berikut.

“...Ya kita sih himbauan, turun langsung kita ini kan kerjanya bareng-bareng, sinergi kan (W1: Iya). Kalo misalnya ada kegiatan konseling kita ikutin. Kalo ada kegiatan kesehatan yang hal-halnya misalnya, sekarang kan angka stunting juga tinggi kan. Ikut kita, nanti mana yang bisa kita bantu, kita bantu. Sebenernya edukasinya itu melalui macem-macem kan. Melalui informasi-informasi papan data, melalui sebaran-sebaran kayak gini, gitu. Itu kan sebenernya tergantung..." (Wawancara mendalam dengan Kepala Seksi Kemasyarakatan dan Pelayanan Kelurahan Tapos, 27 Februari 2020).

Dalam penuturan tersebut dapat dilihat bahwa masyarakat kurang menyadari pentingnya kesehatan dalam kehidupan seharihari, tetapi memang sosialisasi saja tidak cukup, harus diiringi oleh langkah konkret dari Pemerintahan Kota Depok yang langsung menyasar kepada masyarakat melalui kelurahan di Kota Depok. Oleh karena itu, dibutuhkan adanya regulasi dan kebijakan yang menjelaskan tugas pokok dan fungsi secara menyeluruh dan terinci mengenai roadmap kebijakan seperti apa yang dapat membantu menyukseskan berbagai program yang dibuat demi tercapainya efektivitas dan efisiensi dalam pelaksanaan program (Sucipto, 2015).

Pada bagian sebelumnya terlihat beberapa target dari Pemkot Depok yang berfokus pada pembangunan fasilitas dan kapabilitas dari aparat itu sendiri. Fasilitas kesehatan secara umum masih belum dapat dikatakan mencukupi karena masih adanya ketimpangan jumlah puskesmas dan kelurahan serta ketimpangan jumlah puskesmas di kelurahan dengan jumlah penduduk yang menetap. Hal tersebut juga diperparah dengan kondisi tenaga medis yang masih belum optimal. Sebagaimana penuturan dari informan pada kutipan di bawah ini.

“...Kemudian, dengan ehh SDMnya ditingkatkan, ditambah-tambah lah SDMnya (W1: Oh, kualitas) He, eh, jumlah fasilitasnya juga ditambah dengan adanya misalnya di Tapos itu ada 24 jam" (Wawancara mendalam dengan Kepala Seksi Kemasyarakatan dan Pelayanan Kelurahan Tapos, 27 Februari 2020).

Kapabilitas tenaga medis yang belum mencukupi membawa pengaruh terhadap kemampuan masyarakat itu sendiri. Tenaga medis yang ada di tingkat kelurahan karena menjadi ujung tombak dalam membantu masyarakat menyesuaikan diri terhadap perubahan lingkungan dengan adanya ketahanan kondisi kesehatan dari penerapan pola hidup yang dilakukan dan hal tersebut juga akan mempengaruhi kinerja dari puskesmas itu sendiri (Rahayu \& Ginting, 2006). Hal tersebut juga penting bilamana terdapat program yang ditujukan untuk melibatkan partisipasi langsung dari masyarakat itu sendiri. Berdasarkan penuturan dari informan tergambar bahwa masyarakat dilibatkan menjadi salah satu unsur penting dalam mengatasi berbagai risiko penyakit dan mencerdaskan masyarakat lainnya agar memiliki pola hidup sehat.

Pelibatan masyarakat dalam membantu mewujudkan kebijakan SHC melalui pembentukan kaderkader kesehatan yang beranggotakan masyarakat itu sendiri. Proses pengaderan tersebut tergambar melalui kutipan di bawah ini.

“...Yang kalo untuk petugasnya itu mereka harus sudah terutama penanganan kesehatan itu sudah harus ter-registrasi, tenaga yang basicnya kesehatan itu sudah harus ter-registrasi. Kemudian, mereka dibentuk oleh siapa tingkat bawahnya? Tingkat bawah itu adalah kader kesehatan. Kaderkader kesehatan banyak, bale remajanya dan macam-macamnya itu nah mereka melatih, melatih mereka itu" (Wawancara mendalam dengan Kepala Seksi Kemasyarakatan dan Pelayanan Kelurahan Tapos, 27 Februari 2020). 
Lebih lanjut pendaftaran dilakukan secara sukarela dan tidak adanya kualifikasi khusus yang dibutuhkan. Hal tersebut menunjukkan bahwa kegiatan dilakukan secara sukarela secara penuh dan bagi individu yang sudah mendaftar hanya mendapatkan pelatihan selama dua kali dalam setahun. Adapun penugasan utama dari kader itu membuat laporan mengenai kondisi kesehatan dan membantu sosialisasi kebijakan kesehatan. Melihat adanya hal tersebut, peneliti memandang diperlukannya pemutakhiran dari segi manajemen kader kesehatan. Kader-kader kesehatan tersebut sangat potensial dan dapat menjadi salah satu komponen utama untuk mewujudkan kondisi kesehatan yang lebih baik dari sebelumnya. Kaderkader kesehatan tersebut dapat menjadi mitra utama dalam mengubah perilaku masyarakat itu sendiri. Informan juga menjelaskan mengenai kondisi perilaku masyarakat yang memiliki kesadaran yang cukup rendah. Hal tersebut dapat tergambar dari kutipan di bawah ini.

\section{“....Tapi merokoknya gimana? Sudah terbentuk perda, perda loh peraturan daerah tentang KTR (Kawasan Tanpa Rokok). Nahh itu, jadi kesadaran itu, kepedulian itu sebenarnya tergantung dari individu masing-masing. Nah, tadi Ibu kan udah bilang, untuk merubah perilaku itu kan gak kayak membalikkan telapak tangan. Karena itu kan sudah tertanam tanam di benak udah lama." (Wawancara mendalam dengan Herawati, Kepala Seksi Kemasyarakatan dan Pelayanan Kelurahan Tapos, 27 Februari 2020).}

Kutipan tersebut menggambarkan masyarakat yang masih rendah terkait pola hidup sehat karena adanya pengabaian yang dilakukan. Pemkot Depok sendiri sudah melakukan berbagai upaya untuk melakukan sosialisasi salah satunya dengan memberikan edukasi melalui papan informasi yang berada di kantor kelurahan ataupun puskesmas. Hal tersebut belum cukup karena merujuk sebelumnya dari teori Blum, yang sangat berpengaruh terhadap pola hidup sehat masyarakat adalah lingkungan atau masyarakat itu sendiri. Namun, lingkungan yang dapat memberikan dampak positif perlu memenuhi beberapa kualifikasi sebagaimana dikutip dari penelitian Hapsari et al (2009) Fitriany et al (2016) Rehusisma et al (2016) bahwa status kesehatan yang buruk akan lebih berisiko pada masyarakat yang memiliki derajat tingkat pendidikan rendah, tinggal di pedesaan, perokok, dan tempat tinggal yang tidak sehat. Untuk mengatasi hal tersebut perlu dilakukan adanya edukasi dan promosi kesehatan dengan melibatkan kader-kader kesehatan yang sudah terlatih dan diperlukan adanya bantuan dari tenaga medis agar dapat meningkatkan kondisi kesehatan secara berkala dengan penerapan Perilaku Hidup Bersih dan Sehat (PHBS).

Melihat pentingnya hal tersebut diperlukan adanya pemutakhiran dari segi manajemen kader kesehatan dalam mewujudkan SHC. Perbaikan tersebut dapat dilakukan penelaah dari format kader kesehatan yang menjadi praktik sukses di Indonesia. Salah satu praktik sukses yang ada di Indonesia adalah keterlibatan masyarakat dengan menjadi Juru Malaria Kampung (JMK) dan Juru Malaria Perusahaan (JMP) yang ditujukan untuk mengatasi permasalahan malaria di Kabupaten Teluk Bintuni Provinsi Papua Barat yang berhasil menurunkan angka malaria dari 100 per 1.000 penduduk pada tahun 2009 menjadi 1 per 1.000 pada tahun 2016 (Mobilala et al, 2019; Hidayat, 2019). Kunci kesuksesan itu sendiri karena adanya keterlibatan masyarakat yang menjadi JMK dalam mensosialisasikan bahkan memberikan pertolongan pertama bagi pasien yang mengalami gejala malaria. Sekalipun terdapat beberapa permasalahan yang dihadapi oleh Dinas Kesehatan Kabupaten Teluk Bintuni, antara lain sulitnya akses masyarakat terhadap ketersediaan obat yang terbatas, kurangnya tenaga kesehatan, kemampuan petugas medis yang terbatas, model penanggulangan malaria yang rumit, banyaknya obat yang beredar di masyarakat yang tidak berada dalam pengawasan Dinkes Kabupaten Teluk Bintuni dan adanya diagnosa malaria yang tidak berdasarkan prosedur yang tepat sesuai standar (Hidayat, 2019). 
JMK sendiri direkrut secara sukarela dengan mengajak secara inklusif masyarakat dan bagi para JMK yang berasal dari setiap kampung dibekali pengetahuan layaknya petugas kesehatan, bimbingan, dan bahkan terdapat insentif sebesar Rp250.000. Dari segi pendanaan itu sendiri berasal dari Anggaran Pendapatan Belanja Daerah (APBD) dan adanya corporate social responsibility (CSR) yaitu dari British Petroleum (Mobilala et al, 2019). Pelatihan yang dilakukan juga melibatkan kerja sama dari Kementerian Kesehatan untuk dapat mengoptimalkan proses pelatihan tersebut. maupun puskesmas yang ada, meningkatkan kesadaran masyarakat mengenai malaria secara daring (video) dan luring (focus group discussion, poster, brosur, dan papan pengumuman). Melakukan pelatihan untuk empat tambahan JMP, melakukan pelatihan bagi teknisi dari puskesmas berkaitan dengan penggunaan alat seperti mikroskopis, menyediakan 2300 obat malaria dan mendistribusikan di seluruh wilayah, dan melanjutkan bimbingan teknisi terhadap pengembangan RSUD Teluk Bintuni dalam meningkatkan penggunaan alat baru (British Petroleum, 2012). Adanya upaya yang terus dilakukan secara kolaboratif dapat membantu peningkatan kualitas kesehatan di masyarakat.

Seharusnya kader kesehatan yang ditujukan untuk membantu mewujudkan SHC dapat dikelola secara kolaboratif yang melibatkan pemerintah, pihak swasta, masyarakat, akademisi, dan media. Konsep kemitraan ini menekankan pada hubungan kuat tiga aktor yang saling interdependensi satu sama lain dan menghasilkan sistem inovasi nasional antara akademisi/perguruan tinggi, industri, dan pemerintah (Carayannis \& Campbell, 2012).

Konsep kemitraan Quadruple Helix (QH) menambah satu elemen di dalam Triple Helix yaitu masyarakat sipil yang berbasis budaya dan media. Keterlibatan heliks yang keempat menekankan bahwa pemahaman yang lebih luas terkait reproduksi pengetahuan dan aplikasi inovasi membutuhkan peran masyarakat sipil atau pengguna (Arnikll et al, 2010), sehingga lebih terintegrasi ke dalam sistem inovasi yang canggih.

\section{Tabel 4}

\section{Pemutakhiran Manajemen Kader Kesehatan dalam Kebijakan SHC}

\begin{tabular}{|c|c|c|c|}
\hline No- & Tahapan & Aktor & Peran \\
\hline \multirow{4}{*}{1.} & \multirow{4}{*}{ Pembiayaan. } & \multirow{3}{*}{ Pemerintah } & $\begin{array}{l}\text { DLemagulsan pembiayaan kader kesehatan } \\
\text { sebagai salah satu pengeluaran yamg perlu } \\
\text { dibiayai melalui A.PBD. }\end{array}$ \\
\hline & & & $\begin{array}{l}\text { Miemberikan dana alokcasi khusus (DAK) } \\
\text { bidang kesehatan oleh Kementerian } \\
\text { Kesehatan. }\end{array}$ \\
\hline & & & 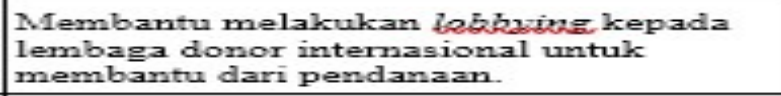 \\
\hline & & Pihak Swasta & $\begin{array}{l}\text { Melakukan aliansi dalam CSR dengan } \\
\text { perusabaan atau badan usaha lainmya. } \\
\text { terutama dalam bidang kesehatam. }\end{array}$ \\
\hline \multirow{4}{*}{2.} & \multirow{4}{*}{$\begin{array}{l}\text { Persiapan dan } \\
\text { Pemberdayaan. }\end{array}$} & \multirow{3}{*}{ Pemerintah } & $\begin{array}{l}\text { M.Iembantu menyiapkan tenaga kesehatan } \\
\text { yang dapat memberikan pelatihan secara. } \\
\text { optimal. }\end{array}$ \\
\hline & & & 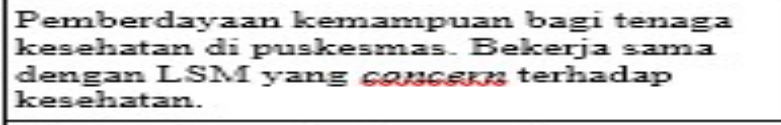 \\
\hline & & & $\begin{array}{l}\text { Pemberdayaan bagi masyarakat yang } \\
\text { menjadi kader kesehatan. }\end{array}$ \\
\hline & & Pihak Swasta & $\begin{array}{l}\text { Memberikam bantuan tenaga kesehatan } \\
\text { dalam membantu pemberday aam bagi } \\
\text { masyarakat ataupun tenaga ahli yang telah } \\
\text { tersertifikasi. }\end{array}$ \\
\hline
\end{tabular}




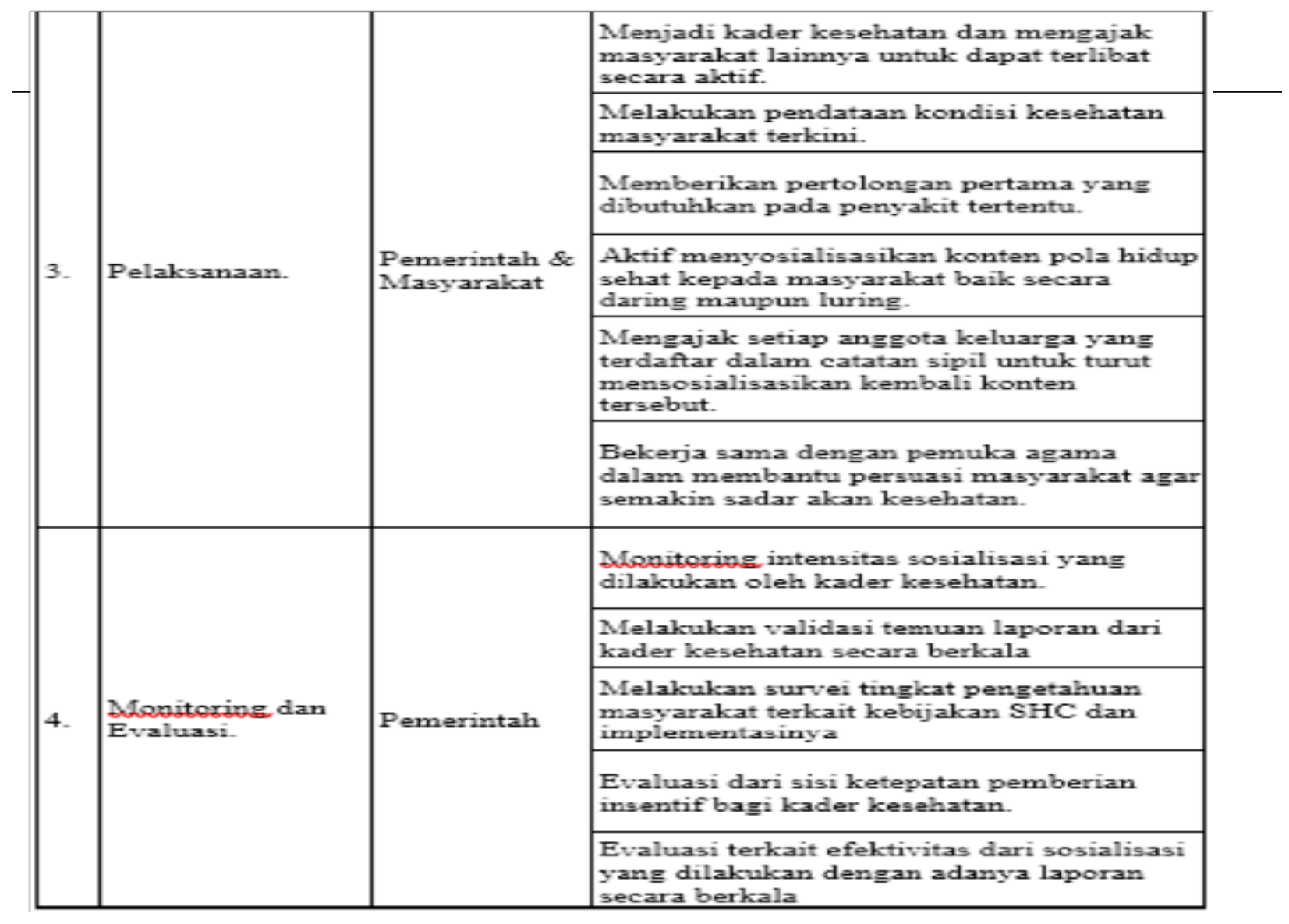

Sumber: Diolah oleh Peneliti, 2020

\section{Analisis Kebijakan Smart Healthy City Depok}

Dalam rangka mewujudkan visi Kota Depok dalam bidang kesehatan, Pemerintah Kota Depok mempunyai program unggulan dalam peningkatan pelayanan kualitas kesehatan agar berjalan secara efektif. Program unggulan tersebut adalah Depok Kota Sehat atau Smart Healthy City. Pada dasarnya konsep Depok Smart Healthy City merupakan konsep dalam mewujudkan sistem kesehatan dengan pemanfaatan teknologi informasi dan komunikasi (TIK) sehingga dapat terintegrasi secara online dan juga bisa berjalan secara efektif dan efisien. Salah satu komponen dalam mewujudkan Smart Healthy City adalah Smart Healthy Citizen. Smart Healthy Citizen merupakan bagaimana kesiapan masyarakat dalam mendapatkan akses informasi kesehatan, mengatur jadwal kesehatan secara online sehingga proses pelayanan administrasi di bidang kesehatan dapat berjalan lebih efektif (Profil Kesehatan Kota Depok, 2018).

Berdasarkan implementasi pada Smart Healthy City Kota Depok melalui hasil wawancara mendalam dengan Ibu Herawati selaku Kepala Seksi Bidang Kemasyarakatan dan Pelayanan Sosial Kelurahan Tapos menyatakan bahwa bentuk sosialisasi terhadap penerapan Smart Healthy City kepada masyarakat belum tersampaikan secara menyeluruh hingga tingkat kelurahan. Seperti pada kutipan yang disampaikan oleh informan di bawah ini:

“..Kalo untuk Smart Healthy City-nya itu gimana, Bu? Udah ada belum si dari Pemerintah Kota Depok terkait sosialisasi lebih lanjut mengenai smart healthy city... (I:Belum, belum) Ohh belum ada. (Wawancara mendalam dengan Herawati, Kepala Seksi Kemasyarakatan dan Pelayanan Kelurahan Tapos, 27 Februari 2020).

Melihat hal tersebut, maka komponen dalam mewujudkan Smart Healthy City melalui Smart Healthy Citizen dalam pemerintahan Kota Depok masih terbilang belum maksimal. Hal ini dikarenakan kurang adanya bentuk sosialisasi yang dilakukan oleh pemerintah Kota Depok 
dalam memberikan pemahaman terkait dengan pemanfaatan Smart Healthy City sehingga masyarakat dapat memahami dan menerapkan sistem pelayanan kesehatan melalui online.

Lebih lanjut, program unggulan yang dicanangkan oleh pemerintahan Kota Depok diperlukan adanya peran dan kontribusi masyarakat untuk ikut serta menyukseskan program Smart Healthy City. Peran masyarakat melalui FKDS (Forum Kota Depok Sehat), FKKS (Forum Komunikasi Kecamatan Sehat) serta Kelompok Kerja (Pokja) Kelurahan sehat harus berperan dalam menjalankan program yang telah dicanangkan oleh pemerintah. Peran dari FKDS dan FKKS selaku dari masyarakat harus bisa mensosialisasikan program Smart Healthy City dari tingkat kota, kecamatan, kelurahan serta RT/RW. Ketua FKDS (depok.go.id, 2019).

Agar tercapainya Smart Healthy City, FKDS terjun langsung ke wilayah untuk melakukan pembinaan kota sehat sehingga apa yang telah di program oleh pemerintah dapat terlaksana dengan baik (Hasanah, 2019). Tetapi dalam realisasinya, berdasarkan hasil wawancara mendalam dengan Ibu Herawati selaku Kepala Seksi Bidang Kemasyarakatan dan Pelayanan Kelurahan Tapos menyebutkan bahwa FKDS dan FKKS belum berjalan secara maksimal dalam mensosialisasikan Smart Healthy City kepada masyarakat. Hal yang menjadi permasalahan dalam hal ini adalah kurangnya kolaborasi antara pemerintah pusat kota Depok dengan tingkat jajaran di bawahnya dalam mensosialisasikan Smart Healthy City. Lebih lanjut, Ibu Herawati menyebutkan bahwa untuk menjalankan suatu program dibutuhkan adanya anggaran khusus (biaya operasional) bagi masyarakat untuk ikut serta terlibat di dalam pembangunan Smart Healthy City. Karena pada dasarnya partisipasi masyarakat masih kurang untuk terlibat dengan tidak adanya uang saku yang diterima dalam menjalankan program pemerintah, terlebih masyarakat tersebut tidak mempunyai pekerjaan yang tetap seperti pada kutipan yang disampaikan oleh informan sebagai berikut

\section{“.. Nah, membuka sesuatu kegiatan itu kan istilahnya harus ehhh ada uang buat ngolah. Sekarang yang ada di situ tidak diberikan misalnya uang ngolah rutin, orang mana mau bekerja? (Wawancara mendalam dengan Kepala Seksi Kemasyarakatan dan Pelayanan Kelurahan Tapos, 27 Februari 2020).}

Berkaitan dengan hal tersebut, maka dalam penerapan Smart Healthy City Kota Depok masih minimnya sosialisasi yang dilakukan oleh pemerintah ataupun masyarakat karena masih tingkat kolaborasi antara Pemkot Depok dan pemerintahan tingkat kelurahan serta masyarakat dalam menjalankan SHC. Pemerintah Kota Depok dengan Dinas Komunikasi dan Informatika (Diskominfo) telah melakukan peningkatan pelayanan di bidang internet ataupun dalam bentuk aplikasi dalam menunjang keberlangsungan Smart Healthy City. Sekretaris Dinas Kesehatan Kota Depok, Ernawati menyebutkan program Smart Healthy City dapat didukung melalui peningkatan pelayanan kesehatan yang berbasis teknologi dengan berintegrasi pada internet. Dalam mendukung program tersebut terdapat tujuh aplikasi yang sudah dimiliki oleh dinas kesehatan Kota Depok untuk mendapatkan pelayanan kesehatan yang lebih baik. Tujuh aplikasi sebagai penunjang Smart Healthy City diantaranya adalah; 1. Sistem Informasi Manajemen Puskesmas (Simpus), 2. Sistem Informasi Puskesmas terkoneksi dengan Primary Care BPJS Kesehatan (Bridging SimpusP.Care), 3. Aplikasi Sistem Informasi Pemetaan Profil Kesehatan Lingkungan (SIPP KLING), 4. Sistem Informasi Kebugaran (Sibugar), 5. Kota Depok Sehat (SiMpok Sehat), 6. Sistem Informasi Pelaporan dan Keamanan Pangan (Sipnap), 7. Sistem Informasi Mandiri dan Waspada Berbasis Masyarakat (Simawas) (Hasanah, 2018). Melihat berbagai aplikasi yang telah dibuat oleh Pemkot Depok, seharusnya sudah memenuhi standar kesiapan smart healthy city dimana adanya penggunaan teknologi dalam proses jalannya pemerintahan untuk memudahkan masyarakat, mengintegrasikan data yang ada, mengumpulkan data sehingga dapat berbagai pakai data dengan dinas lainnya yang ada di Kota Depok bahkan lebih jauh lagi dapat menjadi gambaran kebijakan masa depan yang harus dibuat 
oleh pemerintah kota (Roman \& Miller, 2013). Sangat disayangkan ketika membuka laman dinkes.depok.go.id ketujuh laman yang tertera di atas yang SiMpok Sehat yang dapat diakses itupan masih laman berbentuk uji coba, padahal laman lainnya justru berguna untuk integrasi data dan penyediaan informasi masyarakat agar lebih berimbang dan valid.

Kepala Diskominfo Kota Depok membuat suatu layanan yang dinamakan Mobile Community Access Point (MCAP). Layanan tersebut dimaksudkan untuk mengetahui petunjuk penggunaan internet secara sehat. Salah satu fokus membuat suatu layanan MCAP adalah untuk memberikan peran wanita menuju keluarga sehat dan sejahtera (P2WKS). Dengan adanya layanan tersebut diharapkan mampu mengedukasi masyarakat tentang bagaimana mendapatkan pelayanan kesehatan yang mudah diakses dengan internet (Melyana, 2018). Namun, dalam realisasinya pemerintah kota depok selalu meningkatkan upaya pelayanan berbasis internet tetapi melupakan bentuk sosialisasi yang diberikan kepada masyarakat pada tingkatan kelurahan, RW, dan RT. Meskipun peningkatan pelayanan kesehatan berbasis teknologi dengan terintegrasi secara online sudah dilakukan tetapi pemerintah perlu memperhatikan bentuk sosialisasi kepada masyarakat sehingga masyarakat dapat mengetahui bagaimana cara mendapatkan kesehatan secara efektif ataupun efisien.

Sejalan dengan penetapan program unggulan Smart Health City di Kota Depok, tentunya Pemerintah Kota Depok menyadari pentingnya pengelolaan layanan kesehatan dengan memanfaatkan teknologi informasi dan komunikasi (TIK) secara optimal. Dalam hal ini, Pemerintah Kota Depok melalui Dinas Kesehatan Kota Depok telah menetapkan arah kebijakan sebagai salah satu upaya untuk mewujudkan konsep Smart Health City yakni berupa peningkatan inovasi layanan kesehatan dengan pengembangan sistem informasi Kesehatan (dinkes.depok.go.id, 2018). Hal ini merupakan bentuk respon pemerintah terhadap kemajuan teknologi dalam bidang kesehatan.

Lebih lanjut, kami menganalisis bagaimana upaya Pemerintah Kota Depok dalam penyelenggaraan sistem informasi layanan kesehatan berbasis teknologi informasi sebagai upaya pemenuhan komponen pembangun program Smart Health City di Kota Depok dengan mengacu pada konsep smart health dalam smart city yang dikemukakan oleh Fan et al. (2015). Pertama, ketersediaan sumber data yang akurat merupakan elemen dasar yang dibutuhkan dalam mengembangkan konsep smart health yang mengedepankan integrasi data secara menyeluruh. Dengan mengacu pada Peraturan Pemerintah Nomor 46 Tahun 2014 tentang Sistem Informasi Kesehatan, maka pemerintah pusat melalui Kementerian Kesehatan RI dituntut untuk mengedepankan keterbukaan informasi berupa data kesehatan untuk diakses oleh unit kerja instansi pemerintah daerah (Kementerian Kesehatan RI, 2016). Dalam hal ini, informasi kesehatan yang dimiliki oleh Kementerian Kesehatan RI merupakan sekumpulan data yang dapat menjadi sumber informasi bagi pemerintah daerah tingkat provinsi maupun kabupaten/kota dalam menentukan arah kebijakan dalam rangka mendukung pembangunan kesehatan di masing-masing wilayah. Selain itu, data dan informasi kesehatan yang tersedia juga dapat bersumber dari fasilitas pelayanan kesehatan maupun instansi pemerintah dan pemerintah daerah terkait untuk menjamin keselarasan data dan informasi. Pemanfaatan TIK pada setiap lapisan pemerintahan tentunya merupakan sarana untuk memudahkan penyebarluasan informasi dan memastikan distribusi informasi secara menyeluruh dan berjenjang. Sejauh ini, dapat terlihat bahwa Dinas Kesehatan Kota Depok terus berupaya untuk mengelola dan mendistribusikan informasi yang diterbitkan oleh Kementerian Kesehatan RI maupun sebaliknya.

Hal ini tercermin dari kasus Hepatitis A yang melanda Kota Depok pada akhir 2019 lalu telah mendorong Kementerian Kesehatan untuk mendesak Pemerintah Kota Depok untuk menetapkan status kasus Hepatitis A menjadi Kejadian Luar Biasa (KLB). Selama kasus 
berlangsung, koordinasi antara pemerintah pusat dan daerah terus berjalan untuk memastikan validitas dan keterbaruan informasi (detik.health.com, 2019). Kedua, ketersediaan database yang menghimpun data dan informasi untuk kebutuhan pemrosesan data merupakan salah satu komponen yang dibutuhkan. Dalam hal ini, Pemerintah Kota Depok menyadari urgensi dari keberadaan database sebagai wadah penyimpanan informasi dari seluruh organisasi perangkat daerah (OPD). Dinas Komunikasi dan Informatika (Diskominfo) Kota Depok sebagai pihak yang terus mendorong sistem pelayanan kesehatan berbasis online berencana untuk memberikan kemudahan bagi masyarakat untuk mengakses berbagai data melalui website Depok Open Data. Secara singkat, seluruh OPD nantinya akan dihimbau untuk melakukan input data yang sudah distandarisasi dan disinkronkan dalam server yang dimiliki. Adapun data yang akan dihimpun nantinya dapat diterbitkan dalam situs tersebut (depok.go.id, 2018). Hingga saat ini, Pemerintah Kota Depok belum memiliki database tersebut sehingga data dan informasi yang dimiliki antar OPD belum terintegrasi. Hal ini tentunya menjadi salah satu tantangan dalam pengolahan data yang akan dilakukan oleh aktor yang berkepentingan.

Ketiga, pemusatan data merupakan pengembangan dari kepemilikan database seperti yang telah dikemukakan sebelumnya. Keberadaan database tentunya akan memudahkan instansi pemerintah dalam menciptakan integrasi data dan memastikan keselarasan informasi. Hal ini menjadi salah satu permasalahan yang ditemui di Kota Depok dimana banyaknya sistem informasi layanan kesehatan yang belum dapat diakses secara terbuka dan menyeluruh oleh masyarakat maupun pemangku kepentingan lainnya membuat pengintegrasian data masih menjadi tantangan yang harus dihadapi oleh Pemerintah Kota Depok dalam mewujudkan konsep Smart Health City melihat bahwa smart health dalam artian sebenarnya membutuhkan optimalisasi pemanfaatan TIK dalam berbagai tingkatan yang belum tercermin dari berbagai program yang diluncurkan oleh Pemerintah Kota Depok.

Keempat, pengembangan aplikasi data sebagai platform informasi kesehatan merupakan komponen terakhir dalam pengembangan smart health city. Di Kota Depok sendiri, situs Dinas Kesehatan Kota Depok merupakan situs yang menyediakan informasi seputar kesehatan dan berbagai informasi yang relevan dan dapat diakses oleh khalayak publik. Selain itu, situs ini telah mencantumkan berbagai situs dan link aplikasi terkait dengan program pelayanan kesehatan yang telah dikembangkan oleh Pemerintah Kota Depok. Namun, seperti yang telah disampaikan di atas terlihat bahwa eksistensi berbagai program dan aplikasi yang dikembangkan oleh Pemerintah Kota Depok belum dikelola secara maksimal. Hal ini sangat disayangkan melihat bahwa sejatinya Pemerintah Kota Depok memiliki berbagai infrastruktur yang potensial dalam mencapai tujuan program Smart Health City.

Melihat pentingnya collaborative governance, Pemerintah Kota Depok melalui Smart Healthy City terus melakukan peningkatan dalam segi tata kelola pemerintahan dari berbagai pihak. Dilansir dari (depok.go.id,2017) Pemerintah Kota Depok dalam menyukseskan program Smart Healthy City turut serta melakukan kerja sama dengan pihak kepolisian dan Tentara Nasional Indonesia (TNI). Pihak kepolisian dan TNI melakukan upaya pendekatan untuk memberikan edukasi atau memberikan pendampingan kepada masyarakat yang mengalami permasalahan kesehatan. Sebagai contoh, peram pihak kepolisian dan TNI dalam hal ini adalah untuk memberikan edukasi terhadap penggunaan obat-obat terlarang dengan melakukan pendapatan dari segi agama, medis, psikologis, hingga sosiologis (Indri, 2017).

Namun, walaupun pemerintah kota Depok melakukan kolaborasi dengan Polri dan TNI tetapi kolaborasi dengan masing-masing kelurahan dalam menyukseskan SHC dianggap masih kurang maksimal. Padahal, dalam rencana strategis menyebutkan bahwa Kota Depok ingin mengintegrasikan SHC sampai ke tingkat kelurahan maupun masyarakat ke kelurahan. Melalui hasil wawancara sebagai berikut. 
“..Iya sekarang sebenernya juga ada lagi bantuan dari provinsi Jawa Barat itu, semua $R W$ sudah difasilitasi dengan Android, kalo ga itu salah Android itu untuk Jabar ... apa itu lupa aku lah. Jadi nanti mungkin nelfon itu lewat itu kali kalo ada apa-apa gitu. Kan semua itu kan lapor-laporan terkait udah ada Online-onlinenya kan. (Wawancara mendalam dengan Herawati, Kepala Seksi Kemasyarakatan dan Pelayanan Kelurahan Tapos, 27 Februari 2020).

Kutipan tersebut menggambarkan bahwa bentuk kolaborasi antara pemerintah pusat, dengan kelurahan, ataupun kepada tingkatan RW masih belum berjenjang. Pemerintah Jawa Barat memberikan android kepada RW untuk melaporkan segala bentuk keluhan yang terjadi pada lingkungannya secara online, sehingga tidak melakukan pelaporan ke Kelurahan. Walaupun hal tersebut terbilang secara efektif tetapi penyampaian kolaborasi antara Kelurahan dengan Pemkot Depok belum terlaksana secara maksimal.

Dalam menjalankan program unggulan Smart Healthy City, salah satu usaha yang dilakukan oleh Pemerintah Kota Depok adalah dengan membuat Program Kota Sehat. Program Kota Sehat di Depok ini bersifat berjenjang, dimulai dari di tingkat kota terdapat Forum Kota Depok Sehat, selanjutnya di tingkat kecamatan terdapat Forum Kecamatan Sehat, dan terakhir di tingkat kelurahan dengan Pokja (Kelompok Kerja) Sehat nya. Di dalam Rencana Strategis (Renstra) Dinas Kesehatan Kota Depok, terdapat beberapa upaya yang dilakukan dalam melaksanakan program kota sehat, antara lain: Peningkatan upaya kesehatan masyarakat (UKM) untuk mewujudkan Kota Sehat yang meliputi 7 (tujuh) tatanan; Optimalisasi peran Puskesmas dan forum atau pokja dalam mewujudkan kehidupan masyarakat yang sehat dan mandiri dengan berorientasi kepada proses pola hidup bersih dan sehat, sosialisasi penanganan KLB, penyakit endemik dan penyakit dengan tingkat prevalensi tinggi; Program Kelurahan Sehat; Penjaringan kader atau sukarelawan kesehatan; dan Pemantauan pencapaian Kota Sehat. Lebih lanjut lagi, tercapainya program ini ditunjukkan oleh indikator dari program, yaitu tatanan kota sehat. Kegiatan yang dilaksanakan untuk mendukung tercapainya indikator program ini adalah dengan melakukan pembinaan dan pengembangan kawasan tatanan kota sehat dengan indikator kinerja output berupa: jumlah pembinaan program kota sehat, jumlah tahapan verifikasi kota sehat, dan jumlah pembinaan siaga aktif (dinkes.depok.go.id, 2017).

Berhubungan dengan hal di atas, Pemerintah Kota Depok menerima penghargaan tertinggi sebagai Kota Sehat 2019 atau Swasti Saba Wistara. Penghargaan itu diberikan karena Pemerintah Kota Depok bersama Forum Kota Depok Sehat (FKDS) memenuhi standar kota sehat 2019 yang mengacu pada tujuh tatanan. Tatanan itu adalah kawasan permukiman, sarana dan prasarana umum, kawasan lalu lintas tertib dan pelayanan transportasi, kawasan industri dan perkantoran sehat, kawasan pariwisata sehat, kawasan pangan dan gizi, kehidupan masyarakat sehat yang mandiri, serta kehidupan sosial yang sehat (Tempo, 2019).

Namun, dengan Renstra Dinas Kesehatan Depok yang mengindikasikan program kerja sehat yang dapat mendongkrak keberhasilan Program Depok Smart Healthy City, serta penghargaan yang diterima Pemerintah Kota Depok sebagai Kota Sehat pada tahun 2019, ternyata hal-hal mengenai program Kota Sehat tersebut berkontradiksi dengan temuan peneliti di lapangan. Berdasarkan hasil temuan peneliti, Pokja Kelurahan Sehat yang merupakan turunan dari Program Kota Sehat di Depok belum berjalan dengan baik, bahkan di kelurahan Tapos program tersebut tidak aktif dijalankan oleh masyarakat setempat. Hal ini disebabkan oleh tidak adanya anggaran pengelolaan rutin yang diberikan oleh Pemerintah Kota kepada masyarakat yang mengelola Pokja Kelurahan Sehat tersebut yang berimplikasi pada masyarakat yang bersikap acuh tak acuh karena merasa Pemerintah Kota Depok tidak 
memikirkan anggaran yang seharusnya diberikan kepada setiap individu yang membantu menyukseskan program kesehatan mereka, sebagaimana hasil wawancara peneliti dengan Kepala Seksi Kemasyarakatan dan Pelayanan Kelurahan Tapos:

"Sebenernya program tuh bagus-bagus semua tahun ini, ya ... Ada sih, SK nya, ada siapanya tapi geregetnya belum begitu," ujar Herawati. "Nah, membuka sesuatu kegiatan itu kan istilahnya harus ada uang buat ngolah. Sekarang yang ada di situ (Pokja Kelurahan Sehat) tidak diberikan misalnya uang ngolah rutin, orang mana mau bekerja? (Wawancara dengan Kepala Seksi Kemasyarakatan dan Pelayanan Kelurahan Tapos, 27 Februari 2020).

Anggaran yang diberikan oleh Pemerintah Kota Depok dalam program ini hanya berupa anggaran untuk operasional program tersebut yang diberikan kepada kelurahan dan tidak dianggarkan secara khusus untuk masyarakat yang mengelola Pokja Kelurahan Sehat. Hal ini sebenarnya bisa disiasati dengan menurunkan langsung Aparatur Sipil Negara (ASN) ke setiap kelurahan untuk mengelola program tersebut - tidak perlu dikelola oleh masyarakat, peran masyarakat cukup sebagai subjek program dan pengawas berjalannya program. Selain itu, Pemerintah Kota Depok sebenarnya juga bisa menganggarkan dana untuk diberikan kepada masyarakat pengelola program tersebut, karena berdasarkan Renstra Dinas Kesehatan Kota Depok, tersedia dana untuk kegiatan program pada tahun 2018 yang bersumber dari APBD dan pajak rokok, serta juga tersedia Dana Alokasi Khusus (DAK) NonFisik dan Bantuan Operasional Kesehatan (BOK) yang digunakan untuk pelaksanaan teknis di tingkat kelurahan untuk kegiatan pengembangan dan pemberdayaan masyarakat dalam mendukung pencapaian Tatanan Kota Sehat (dinkes.depok.go.id, 2017).

Seharusnya dengan tersedianya danadana tersebut, anggaran untuk masyarakat yang mengelola Pokja Kelurahan Sehat bisa dialokasikan. Perencanaan dari renstra tersebut tentu saja bertolak belakang dengan kenyataan di kelurahan Tapos, seperti yang dideskripsikan berikut ini:

"Anggaran itu adanya di kelurahan, silakan mereka membuat program. Tapi kan istilahnya untuk yang mengelola program itu kan ada khusus. Sama dengan kader posyandu, kader posyandu itu tidak mendapatkan honor secara rutin, tapi dia hanya mendapatkan operasional. ... Per individu gak ada. ... Sekarang ehh masyarakat di suruh untuk istilahnya ehh bikin nih kegiatan program kota sehat, kegiatan seperti ini, seperti ini, seperti ini. Mereka sebenernya sudah siapkan nih itunya, rumahnya, nih silakan kamu membuat kebijakan. Tapi untuk yang bersangkutan gak ada secara khusus, ya orang kalo gak dikasih honor gimana mas? Mana mau sih mikir? Ya udah istilahnya sekedar di atas kertas lah yang penting udah ada nih kelurahan Tapos misalnya udah ada yang namanya pokja sehat, ada." (Wawancara dengan Kepala Seksi Kemasyarakatan dan Pelayanan Kelurahan Tapos, 27 Februari 2020).

Berdasarkan pernyataan di atas, dapat disimpulkan bahwa terdapat ketidakselarasan antara perencanaan dalam renstra dinas kesehatan Depok mengenai program Pokja Kelurahan Sehat dengan implementasinya di kelurahan Tapos. Hal ini terjadi karena perencanaan yang kurang matang dari Dinas Kesehatan Depok dalam hal penganggaran program yang menyebabkan program tersebut tidak berjalan secara efektif. Pada akhirnya, seperti yang dituturkan oleh Ibu Hermawati, program Pokja Kelurahan Sehat tersebut hanya menjadi sekadar formalitas di atas kertas untuk menunjukkan adanya kepedulian pemerintah Depok terhadap kesehatan masyarakatnya, khususnya masyarakat di kelurahan Tapos. 
Melihat kenyataan yang ada, salah satu komponen dari terciptanya smart city adalah adanya smart citizen dimana seharusnya masyarakat mampu menggunakan teknologi, data, menciptakan inovasi, memiliki kesadaran diri akan perubahan lingkungan, serta mendukung kebijakan yang ada untuk kesejahteraan, tetapi melihat kembali kenyataan yang ada di Kota Depok, nampaknya pemenuhan dari aspek smart citizen jauh dari kata tercapai (Cardullo \& Kitchin, 2018).

Selanjutnya, ketika meninjau dari aspek smart governance untuk terciptanya smart healthy city, maka harus melihat dari komponen penting yang ada dalam pelaksanaan smart governance itu sendiri. Diantaranya mencakup kesiapan organisasi pemerintah, partisipasi masyarakat dimana di dalamnya terdapat kolaborasi antara pemerintah, sektor swasta, lembaga non pemerintah dan masyarakat serta penggunaan teknologi (Tomor, Meijer, Geertman, \& Michels, 2019). Selain itu, adanya komitmen, responsivitas tinggi, dan manajemen yang memiliki panduan kerja yang jelas juga harus dimiliki pemerintah dalam pengimplementasian smart governance (Przeybilovicz, Cunha, \& Tomor, 2017). Hal tersebut masih menjadi pekerjaan yang harus diselesaikan oleh Pemkot Depok terutama responsivitas terhadap pembuatan tugas dan fungsi pokok yang jelas dan terarah jika ingin menjadi smart healthy city, tidak hanya melalui RPJMD, tetapi juga bisa melalui Peraturan Wali Kota yang disosialisasikan secara menyeluruh agar masyarakat juga turut serta mendukung tercapainya SHC Depok, selaras dengan informasi yang didapatkan dari narasumber peneliti bahwa kolaborasi dan sosialisasi mengenai smart healthy city Depok belum sepenuhnya didesentralisasikan hingga ke kelurahan, padahal dalam RPJMD Kota Depok 2016-2021, kelurahan memiliki peranan penting dalam mendukung terciptanya smart healthy city.

Komponen selanjutnya yang tidak kalah penting dengan kemampuan organisasi pemerintah dalam rangka mencapai smart city adalah partisipasi masyarakat dimana partisipasi masyarakat akan memberikan saran yang berguna, lebih baik, dan sesuai dengan keputusan kebijakan yang akan ditetapkan oleh pemerintah (Hujran, Aloudat, \& Altarawne, 2013). Pemerintah Kota Depok hendaknya memetakan partisipasi masyarakat terlebih dahulu sebelum menjadikan smart healthy city suatu kebijakan program unggulan hingga tahun 2021. Pemetaan dapat dilakukan melihat sejauh mana bentuk-bentuk partisipasi masyarakat dalam tata kelola bersifat interaktif yang akan menghasilkan sebuah kebijakan yang mewakili masyarakat, seberapa banyak keterwakilan populasi yang berpartisipasi, dan apa yang mendukung motif bagi warga agar berpartisipasi (Arnstein, 1969).

\section{Simpulan}

Smart Healthy City Depok merupakan salah satu kebijakan yang mutakhir mengingat bahwa kualitas kesehatan merupakan salah satu hak yang dimiliki oleh tiap individu. Tetapi, kebijakan tersebut harus dimutakhirkan mengingat bahwa kebijakan tidak hanya dibuat berdasarkan collective problems yang ada melainkan melihat dari sisi nilai, kemampuan, dan pengetahuan yang ada di tiap-tiap lokus dimana kebijakan tersebut diterapkan. Pengembangan kapabilitas dan penyesuaian manajemen anggaran menjadi sorotan penting bagi SHC di Kota Depok mengingat bahwa kebijakan tersebut melibatkan kolaborasi dari berbagai pihak dan menjadi program unggulan Kota Depok. Selain itu, pemerintah hendaknya memerhatikan aspek terkait penamaan smart healthy city itu sendiri yang mencakup smart citizen, smart governance, partisipasi masyarakat, hingga penggunaan teknologi dalam proses pemerintahan. Kebijakan smart healthy city yang didesentralisasikan hanya sekedar formalitas berupa sosialisasi tanpa adanya pelatihan berkelanjutan, hal tersebut menjadi permasalahan ketika tiap organisasi pemerintahan tingkat kelurahan tidak dapat memahami dan menyampaikan kembali maksud dan tujuan Pemkot Depok terkait smart healthy city. 


\section{Referensi}

Ansell, \& Gash, 2007. Collaborative Governance in Theory and Practice. Oxford University Press.

Anthopoulos, L. (2017). Understanding Smart Cities: A Tool for Smart Government or an Industrial Trick? Switzerland: Springer.

Arnkill, R., et al. (2010). Exploring Quadruple Helix Outlining User-Oriented innovation models Final Report on Quadruple Helix Research for the CLIQ project, under the Interreg IVC Programme.

Arnstein. (1969). A Ladder of Citizen Participation. Journal of the American Institute of Planners 35: 4, 216-224.

Caragliu, A., Del Bo, C., \& Nijkamp, P. (2011). Smart Cities in Europe. Journal of Urban Technology, 18(2), 65-82.

Carayannis, E. G., Barth, T. D., \& Campbell, D. F. J. (2012). The Quintuple Helix Innovation Model: Global Warming as A Challenge and Driver for Innovation. Journal of Innovation and Entrepreneurship 2012. 1(2), 4-24.

Cardullo, P., \& Kitchin, R. (2018). Smart urbanism and smart citizenship: The neoliberal logic of 'citizen-focused' smart cities in Europe. Cardullo, P., \& Kitchin, R. (2018). Smart urbanism and smart citizenship: The neoliberal logic of "citizen-focused" smart cities in Europe. Environment and Planning C: Politics and Space, 1-18.

Fan, M., Sun, J., Zhou, B., \& Chen, M. (2015). The Smart Health Initiative in China: The Case of Wuhan, Hubei Province. Journal of Medical Systems, 40(3), 1-17.

Fauzi, A., R., \& Rahayu, A., Y., S. (2019). Collaborative Governance Penanganan HIV AIDS di Provinsi DKI Jakarta. Sawala Jurnal Administrasi Negara Vol.7 No.1.

Fitriana, E., N. (2017). Collaborative Governance dalam Penanggulangan HIV dan AIDS di Daerah Istimewa Yogyakarta. Tesis. Universitas Gadjah Mada.

Fitriany, M., S., Farouk, H., M., \& Taqwa, R. (2016). Perilaku Masyarakat dalam Pengelolaan Kesehatan Lingkungan (Studi di Desa Segiguk sebagai Salah Satu Desa Penyangga Kawasan Hutan Suaka Margasatwa Gunung Raya Ogan Komering Ulu Selatan. Jurnal Penelitian Sains Vol. 18 Nomor 1.

Hapsari, D., Sari, P., \& Pradono, J. (2009). Pengaruh Lingkungan Sehat, dan Perilaku Hidup Sehat Terhadap Status Kesehatan. Buletin Penelitian Kesehatan Supplement 2009: 4049.

Hidayat, H., Y. (2019). Implementasi Sistem Early Diagnosis Accurate Treatment (EDAT) dalam Pengentasan Malaria di Kabupaten Teluk Bintuni. In Kumorotomo, W. (2019). Kebijakan Publik Kontemporer: Analisis Kumpulan Kasus Kebijakan di Indonesia. IGPA Press.

Hujran, A., Aloudat, \& Altarawne. (2013). Factors Influencing Citizen Adoption of EGovernment in Developing Countries: The Case of Jordan. International Journal of Technology and Human Interaction 9: 2, 1-19.

Ihsanudin, I., \& Rahayu, A.Y. (2019). Collaborative Innovation in Digital Ecosystem. DOI:10.4108/eai.7-12-2018.2281772.

Laila, N. H., \& dkk. (2018). Faktor Risiko Terjadinya Kejadian Luar Biasa (KLB) Hepatitis A di Kabupaten Tangerang Tahun 2016. Jurnal Epidemiologi Kesehatan Indonesia, 1-6. 
Mohanty, S., Choppali, U., \& Kougianos, E. (2016). Everything You Wanted to Know About Smart Cities. IEEE Consumer Electronics Magazine, 5(3), 60-70.

Muqirrobin, M. (2016). Collaborative Governance dalam Bidang Kesehatan (Studi Pelaksanaan Kolaborasi Pengendalian Penyakit TB-HIV di Kabupaten Blitar. Tesis. Universitas Airlangga.

Nuraini, S. (2015). Collaborative governance antar stakeholders dalam Pelaksanaan Program- Program Penanggulangan HIV/AIDS di Kota Surakarta”.Tesis, Universitas Sebelas Maret.

Przeybilovicz, Cunha, \& Tomor. (2017). Identifying Essential Organizational Characteristics For Smart Urban Governance. Proceedings of the 18th Annual International Conference on Digital Government Research, 416-425.

Rahayu, A., Y., S., \& Ginting, B. (2006). Kinerja Tiga Puskesmas di DKI Jakarta Berdasarkan Perspektif Balanced Scorecard. Jurnal Penyuluhan Vol. 2 No. 4.

Rehusisma, L., A., Indriwati, S., E., \& Suarsini, E. (2016). Studi Eksplorasi Perilaku Hidup Bersih dan Sehat Bagi Masyarakat di Kabupaten Malang. Pros. Semnas Pend. IPA Pascasarjana UM, Vol.1, 2016.

Roman, \& Miller. (2013). New Questions For E-Government: Efficiency But Not (Yet?) Democracy. International Journal of Electronic Government Research 9: 1, 65-81.

Simsek, M., Obinikpo, A., \& Kantarci, B. (2020). Deep Learning in Smart Health: Methodologies, Applications, Challenges. In A. Saddik, M. Hossain, \& B. Kantarci, Connected Health in Smart Cities. Switzerland: Springer.

Suwardana, H. (2017). Revolusi Industri 4.0 Berbasis Revolusi Mental. Jati Unik, 102-110.

Swastini, A. (2010). Collaborative Governance Komisi Penanggulangan AIDS dan Lembaga Swadaya Masyarakat Lokal dalam Kasus HIV \& AIDS di Kota Surakarta. Tesis. Universitas Sebelas Maret.

Tomor, Z., Meijer, A., Geertman, S., \& Michels, A. (2019). Smart Governance For Sustainable Cities: Findings from a Systematic Literature Review. Journal of urban technology volume 26, 3-27.

Widiastuti, I. (2017). Pelayanan Badan Penyelenggara Jaminan Sosial (BPJS) Kesehatan Jawa Barat. Jurnal Ilmiah WIDYA, 224-233.

\section{Media Elektronik}

Adi. (2019, November 17). Walikota Hadiri HKN, Kampanyekan Germas. Retrieved from depokpro: https://www.depokpro.com/2019/11/17/walikotahadiri-hkn-kampayekange mas/

Alam, S. O. (2019, November 25). Kemenkes Dorong Pemkot Depok Tetapkan Status KLB Hepatitis $A$. Retrieved from detikHealth:

https://health.detik.com/berita-detikhealth/d-4797470/kemenkes-dorongpemkot-depoktetapkan-status-klb-hepatitis-a

Billy, A. T. (2019, Desember 5). Perkembangan Hepatitis A di Depok, Jumlah Terkini Mencapai 262 Kasus. Retrieved from tribunnews.com: 
https://www.tribunnews.com/kesehatan/2019/12/05/perkembangan-hepatitisa-didepok-jumlah-terkini-mencapai-262-kasus

CNNIndonesia. (2019, Desember 5). Depok KLB Hepatitis A, Pemkot Gratiskan Pengobatan. Diambil kembali dari CNN Indonesia.com: https://www.cnnindonesia.com/nasional/20191205132632-20-454415/depokklbhepatitis-a-pemkot-gratiskan-pengobatan

depok.go.id. (2018). Pemkot Depok Beri Kemudahan Akses Data Via Online. Retrieved from https://www.depok.go.id/03/02/2018/01-beritadepok/pemkot-depok-beri-kemudahanakses-data-via-online

detik.health.com. (2019). Kemenkes Dorong Pemkot Depok Tetapkan Status KLB Hepatitis A. Retrieved from https://health.detik.com/berita-detikhealth/d-4797470/kemenkesdorong-pemkot-depok-tetapkan-status-klb-hepatitis-a

Hasanah, N. (2019, November 19). 3.000 Warga Diajak Dukung Germas. Diambil kembali dari Depok.go.id: https://www.depok.go.id/16/11/2019/01berita-depok/3-000-wargadiajak-dukung-germas

Hasanah, N. (2018, September 24). Smart Healthy City Mudahkan Masyarakat Mengakses Pelayanan Kesehatan. Retrieved from depok.go.id: https://www.depok.go.id/24/09/2018/01-berita-depok/smart-healthy-citymudahkanmasyarakat-mengakses-pelayanan-kesehatan

Hasanah, N. (2019, Juni 27). Smart Healthy City Diimplementasikan Lewat Pelayanan Kesehatan Berbasis Online. Retrieved from depok.go.id: https://www.depok.go.id/27/06/2019/01-berita-depok/smart-healthycitydiimplementasikan-lewat-pelayanan-kesehatan-berbasis-online

kominfo.go.id. (2015, oktober 25). Revolusi Mental: Membangun Jiwa Merdeka Menuju Bangsa Besar. Diambil kembali dari kominfo.go.id: https://kominfo.go.id/index.php/content/detail/5932/Revolusi+Mental\%3A+ Membangun+Jiwa+Merdeka+Menuju+Bangsa+Besar/0/artikel_gpr

Kotasehat.depok.go.id. (2020). Sistem Informasi Kota Depok Sehat. Diambil kembali dari kotasehat.depok.go.id: http://kotasehat.depok.go.id

Marques, J. (2019, September 4). Wujudkan Kota Sehat, Warga Sukamaju Diberi Sosialisasi STBM. Retrieved from depok.go.id https://www.depok.go.id/04/09/2019/01-berita-depok/wujudkan-kota-sehatwargasukamaju-diberi-sosialisasi-stbm

Marques, J. (2018, Oktober 25). Peringati Hari Kesehatan, UPT Puskemas Tapos Gelar Gebyar Germas. Diambil kembali dari depok.go.id: https://www.depok.go.id/25/10/2018/01-berita-depok/peringati-harikesehatan-uptpuskesmas-tapos-gelar-gebyar-germas

Melyana, S. (2018, April 23). Wujudkan Smart Healthy City, Diskominfo Kota Depok Sosialisasikan Layanan MCAP. Retrieved from siarandepok.com: http://www.siarandepok.com/baca/20180423/wujudkan-smart-healthycitydiskominfo-kota-depok-sosialisasikan-layanan-mcap.html

Putra, B. (2019, Februari 25). Puluhan Puskesmas di Depok Kekurangan Ratusan Tenaga Medis. Retrieved Februari 25, 2020, from TribunJakarta.com: https://jakarta.tribunnews.com/2019/02/25/puluhan-puskesmas-di-depokkekuranganratusan-tenaga-medis 
Rubiakto. (2020, nd.) Edukasi Masyarakat Depok Jaga Kesehatan. Retrieved from radardepok: https://radardepok.com/2020/01/edukasi-masyarakatdepok-jaga kesehatan/

setkab.go.id. (2015, Februari 25). Apa Yang Perlu Diketahui Untuk Membuat Peraturan Perundang-Undangan? Diambil kembali dari setkab.go.id: https://setkab.go.id/apayang-perlu-diketahui-untuk-membuat-peraturanperundang-undangan/

Simatupang, G. (2019, Februari 25). Sampai Kini Ada 23 Kelurahan di Depok Tak Punya Puskesmas. Retrieved Februari 25, 2020, from Wartakota.com: https://wartakota.tribunnews.com/2019/02/25/sampai-kini-ada-23-kelurahandi-depoktak-punya-puskesmas

Tempo. (2019, November 20). Tujuh Kriteria Ini Antar Depok Raih Penghargaan Kota Sehat. Retrieved from Tempo.co: https://metro.tempo.co/read/1274409/tujuh-kriteriaini-antar-depok-raihpenghargaan-kota-sehat/full\&view $=$ ok

Wiyanti, W. (2019, Desember 5). Begini Kronologis Mewabahnya KLB Hepatitis A di Depok. Retrieved from detikHealth: https://health.detik.com/beritadetikhealth/d4810489/begini-kronologis-mewabahnya-klb-hepatitis-a-didepok 